収帯は，ポリグルタミン酸メチルの低重合体の $\beta$ 型 慗造のとき $700 \mathrm{~cm}^{-1}$ に現われ，第 1 報の $\alpha$-Helix 構 气の $620 \mathrm{~cm}^{-1}$ との相違が大なることより，分子立体構 きの解明にきわめて有用であることがわかった。

付 記: 本研究の一部は第 10 回高分子学会年次大会(昭和 36 年 5 月)において発表した。なお本研究は昭和 35 年度大阪 大学蛋白質研究所共同研究員制度によって行なわれた。ご指導 いただいた同研究所官沢辰雄助教授，およびご援助いただいた 物理構造部の方々に感新する。

\section{文献}

1）増田幸夫：高化，20，161(1963)

2) E. R. Blout, A. Asadourian: J. Am. Chem. Soc., 78, 955(1956)

3）宮沢辰雄：日化，77，526(1956)

4） DL 共重合体に関しては, 最近に次の文献がある。 M. Goodman et al: J. Am. Chem. Soc., 84, 1288 (1962)

\title{
Molecular Structures of Polyglutamate
}

\section{Infrared Absorption Spectra of Low Polymeric $\gamma$-Methyl Glutamate}

\author{
By Yukio Masuda*
}

\begin{abstract}
Some low polymeric $\gamma$-methyl L-glutamates were synthesized. Infrared absorption spectra of these polymers and $\mathrm{N}$-deuterated derivatives were measured. The amide $\mathrm{V}$ band of the $\beta$ (extended) structure of polypeptides was observed at $700 \mathrm{~cm}^{-1}$, which is well distinguished from the absorption band of the $\alpha$-Helix at $620 \mathrm{~cm}^{-1}$. It is shown that the amide $\mathrm{V}$ band is useful for the investigation of the spatial structure of polypeptide molecules.
\end{abstract}

第 3 報 ポリグルタミン酸 $\gamma$-ベンジルエステルの赤外線吸収

(1962 年 8 月 28 日受理)

増 田 幸 夫**

\begin{abstract}
要旨従来合成ポリペプチドとしてよく取り上げられてきたポリグルタミン酸ベンジルエステルの固 体薄膜の赤外線吸収スペクトルを新たに測定し，その低波数領域において，NH 面外変角振動によるアミド V 吸收帯が, 分子の空間嚅造に鋭敏に対応して変化することを見出した。前報のメチルエステルの場合と同じよ うに,ベンジルェステルにおいても，アミド V 吸収帯は, $\alpha$-Helix 構造のとき $615 \mathrm{~cm}^{-1}, \beta$ 型構造のとき ほほ $700 \mathrm{~cm}^{-1}$ に現われることがわかった。
\end{abstract}

\section{1. 緒言}

第 1 報1)で述べたように，高分子量ポリグルタミン酸 チルの固体薄膜の赤外楾吸収スペクトルには, $\alpha-$ elix に特有なアミド吸収帯がレくつか存在し，特に低 擞領域の $620 \mathrm{~cm}^{-1}$ の強い吸収带は, 赤外二色性と, 重水素置換の結果によって, 主として NH 面外变角 慟による、いわゆるアミド V 吸収带2であることがわ

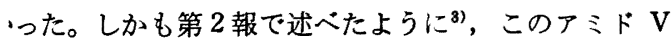
收帯は, 低分子量のポリグルタミン酸メチルの赤外線 叹では, 波数が著しく変化して, 約 $700 \mathrm{~cm}^{-1}$ に現わ 、るともわかり，このように波数差の大きいことは， 涞のアミド I, II による立体構造の識別よりも", もっ
と明りょうな認定法になりらることが予想されるに至っ た。な损 DI, 共重合体のアミド V 吸収带の強度を比較 すれば， $\alpha$-Helix の含量の定量も可能であると思われ る。ここでは,このようなポリペプチドのアミド V 吸 収帯が他の例, すなわち今までに多くの人達によって用 いられてきたポリグルタミン酸ベンジルエステルにおい ても，明りょうに存在することを示し，有用性をさらに 確認しようとした。

\section{2. 試 料}

用いたポリグルタミン酸ベンジルェステルは,すべて NCA 法で合成したもので，方法については特に新しい ところはない。高分子量のものは, ジオキサン溶液で重

\footnotetext{
* Department of Physics and Chemistry, Gakushuin University (1-Chome, Mejiro, Toshima, Tokyo)
}

** 学習院大学理学部化学教室(東京都曹岛区目白町 1 丁目) 
合開始剤に $\mathrm{CH}_{3} \mathrm{ONa}$ を用い, $A / I=200$ で重合し ${ }^{5)}$, 低 分子量のものは, 同じくジオキサン溶液で, $n$-ヘキシル アミンを重合開始剤として $A / I=4,8,20$ で重合した ${ }^{6)}$ 。 また L-NCA と D-NCA とを $\mathrm{L} /(\mathrm{D}+\mathrm{L})=100,95,75$, $60,50 \%$ の割合に混合し、ジオキサン溶媒, $\mathrm{CH}_{8} \mathrm{ONa}$ 開 始剂, $A / I=200$ で重合し, 共重合体を合成して試料と した。ジクロル酢酸中の溶液粘度測定よりの分子量・重 合度 ${ }^{7}$ は Table 1 に示す。試料 No. 1 5 と 6 8 とは 異なった原料エステルから異なった時期に合成したもの で, そのまま重合度を比較することは無理であり, 後に 述べる赤外線吸収の結果より, 異なった分子構造が推定 された。

\section{3. 結果と考察}

赤外線吸収スペクトルはいずれも試料重合体を，5\% クロロホルム溶液として, 白化カリ板上に塗り, 溶媒を とばして固体薄膜として測定した。赤外二色性, $\mathrm{N}$ 重水 素化についても前報と同様に行なった。

Fig. 1 に高重合度ポリ-L-グルタミン酸ベンジルにつ いての測定結果を示す。アミド I, II よりみて, これは
Table 1. Degree of polymerization of poly benzyl glutamates.

\begin{tabular}{|c|c|c|c|c|}
\hline No. & $\frac{\mathrm{L}}{\mathrm{D}+\mathrm{L}}$ or $\frac{A}{I}$ & $\begin{array}{l}{[\eta] \text { in }} \\
\text { DCA }\end{array}$ & $\begin{array}{c}\bar{M}_{w} \\
\times 10^{-3}\end{array}$ & $P_{w}$ \\
\hline 1 & 100 & 0.11 & 14.1 & 64 \\
\hline 2 & 95 & $0.28 *$ & 39.1 & 180 \\
\hline 3 & 75 & 0.09 & 11.4 & 52 \\
\hline 4 & 60 & 0.09 & 11.0 & 50 \\
\hline 5 & 50 & 0.07 & 8.1 & 37 \\
\hline 6 & 4 & 0.08 & 9.7 & 44 \\
\hline 7 & 8 & 0.11 & 14.0 & 64 \\
\hline 8 & 20 & 0.17 & 30.0 & 140 \\
\hline
\end{tabular}

* Recrystallisation of NCA was much more one time

完全な $\alpha$-Helix である“低波数領域の $614 \mathrm{~cm}^{-1}$ に 強、吸収帯があり,この吸収帯は $\mathrm{L} /(\mathrm{D}+\mathrm{L})=95,7$ ! $60 \%$ と，D 残基が入るに従って, 強度が隇少するの: 見られる。Fig. 2 に示すように, L:D=1:1の DL

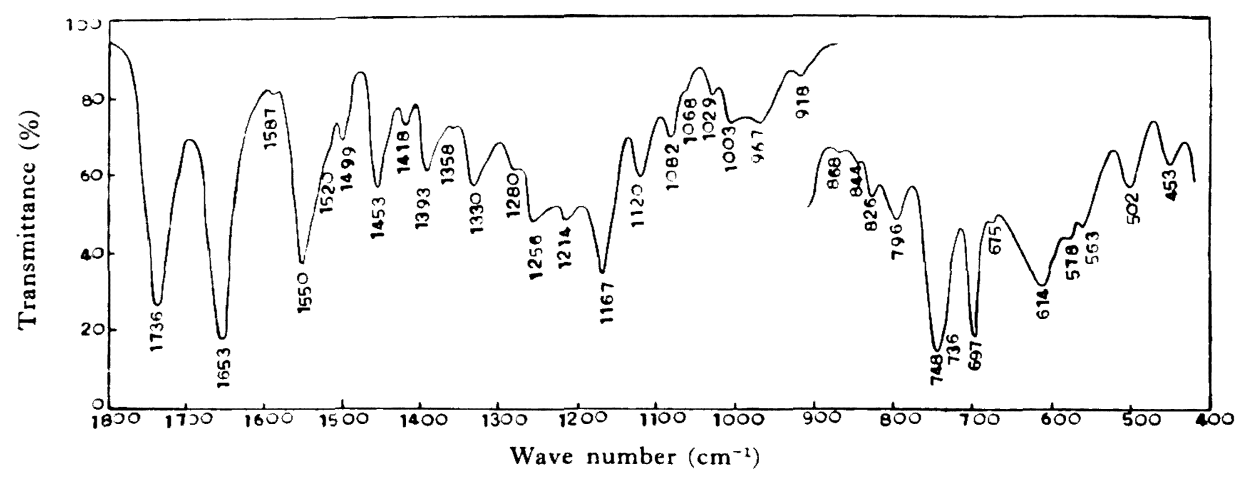

Fig. 1. Infrared spectra of poly $\gamma$-benzyl L-glutamate.

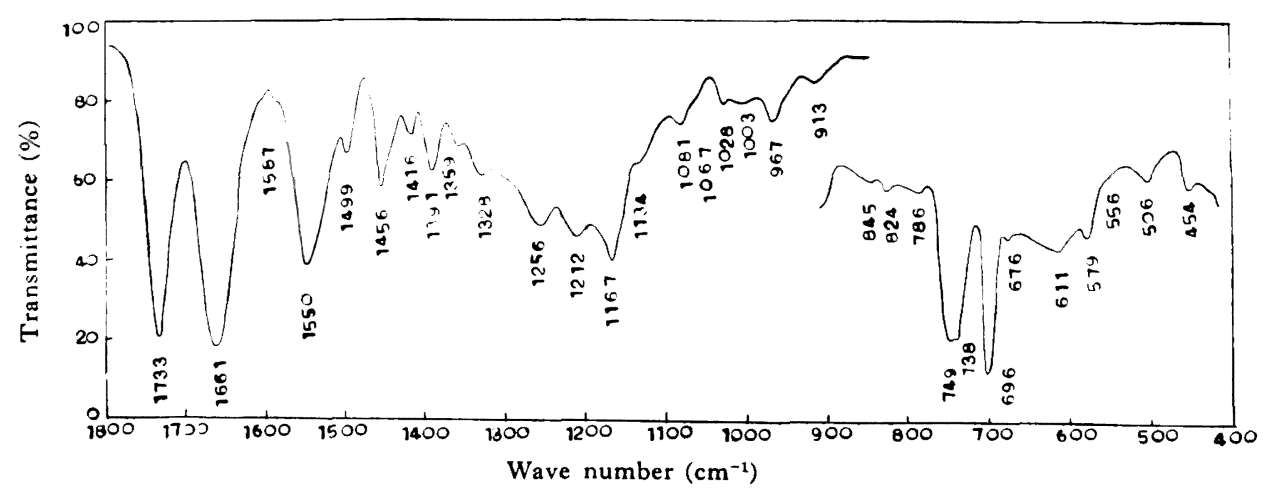

Fig. 2. Infrared spectra of poly $\gamma$-benzyl $D L$-glutamate $(L: D=1: 1)$. 
自合体では，これも $\alpha$-Helix が存在することは確実だ 今, $610 \mathrm{~cm}^{-1}$ 辺の吸收帯注相当に弱いものとなってい う。純 L 重合体のとき右巻き Helix, 純 D 重合体のと 左巻き Helix といわれているから ${ }^{8)}$, DL 共重合体で 丈, Helix 含量はいくらか変化し減少することが考えら
れる。そこでこの吸収帯は $\alpha$-Helix によるものと推定 できる。さらにこの吸収带の性格について調べるため, $\mathrm{N}$ 重水素化試料について測定した。Fig. 3 に PBLG-d を示す。 $614 \mathrm{~cm}^{-1}$ の強い吸収帯は消失し，かわって $458 \mathrm{~cm}^{-1}$ に新しい強い吸収帯が現われている。この波

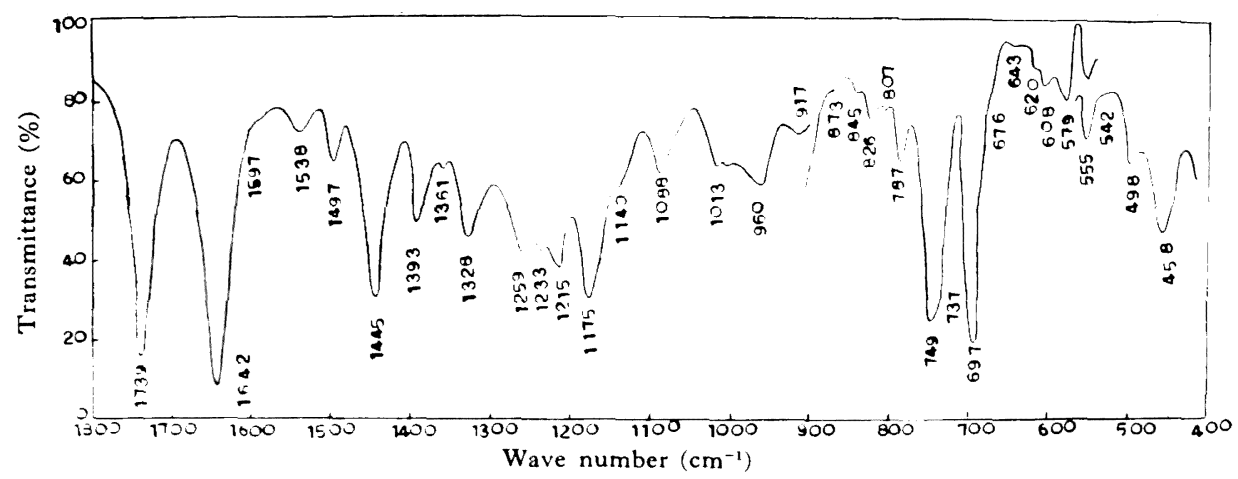

Fig. 3. Infrared spectra of $\mathrm{N}$-deuterated poly benzyl L-glutamate.

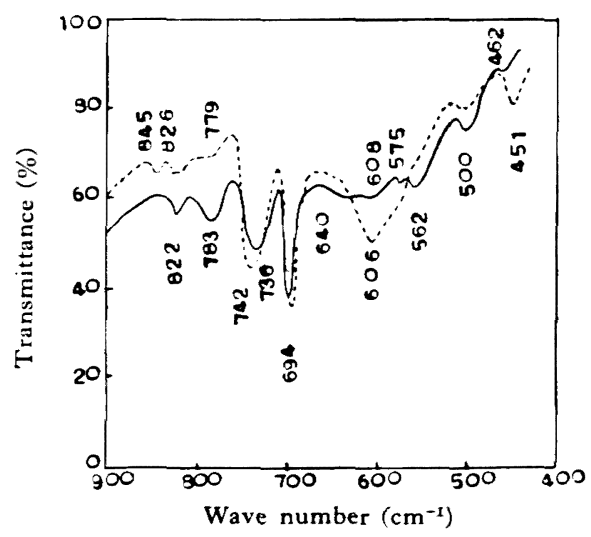

Fig. 4. Polarized infrared spectra of poly benzyl L-glutamate.

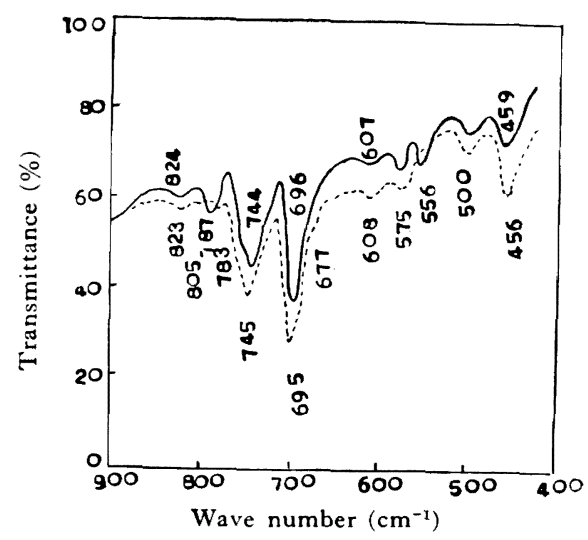

Fig. 5. Polarized infrared spectra of $\mathrm{N}-$ deuterated poly benzyl L-glutamate.

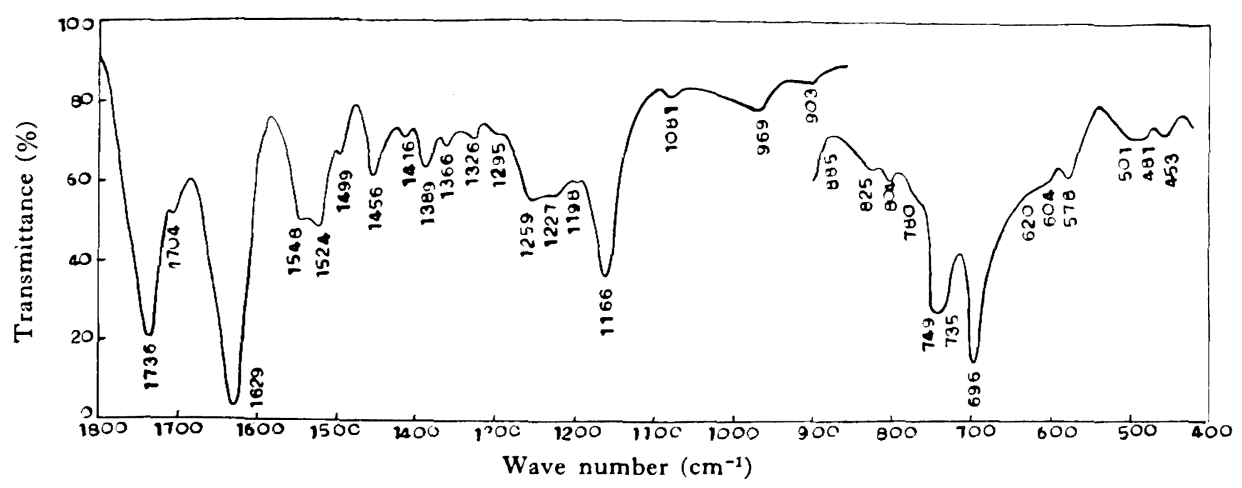

Fig. 6. Infrared spectra of poly benzyl L-glutamate $A / I=4$. 
数比は $458 / 614=1 / 1.34$ で, $\mathrm{NH}$ 面外変角振動によるア ミド V 吸収帯と推定される2)。さらに確認のため, 臭化 カリ領域の赤外二色性を測定した結果が，Fig. 4, 5 で， PBLG の $606 \mathrm{~cm}^{-1}$, PBLG-d の $456 \mathrm{~cm}^{-1}$ は, 垂直吸 収帯であるから，ここで $\alpha$-Helix 構造をとるポリグル タミン酸ベンジルのアミド V 吸収帯として 615 $\mathrm{cm}^{-1}$ が確定した。
PBLG では, 796, $563 \mathrm{~cm}^{-1}$ にも吸収帯がありここ は D 残基が入るに従ってすぐに消失し, PMDLG で 全く見られない。これらの吸収帯は $\mathrm{N}$ 重水素化 $787 \mathrm{~cm}^{-1}$ と $555 \mathrm{~cm}^{-1}$ に移動するから, CONH の結 には関係するものと思われる。 $563 \mathrm{~cm}^{-1}$ の吸収帯は そらく $\mathrm{CO}$ の面外変角振動によるものであろら。これ メチルェステルの場合にも存在した。

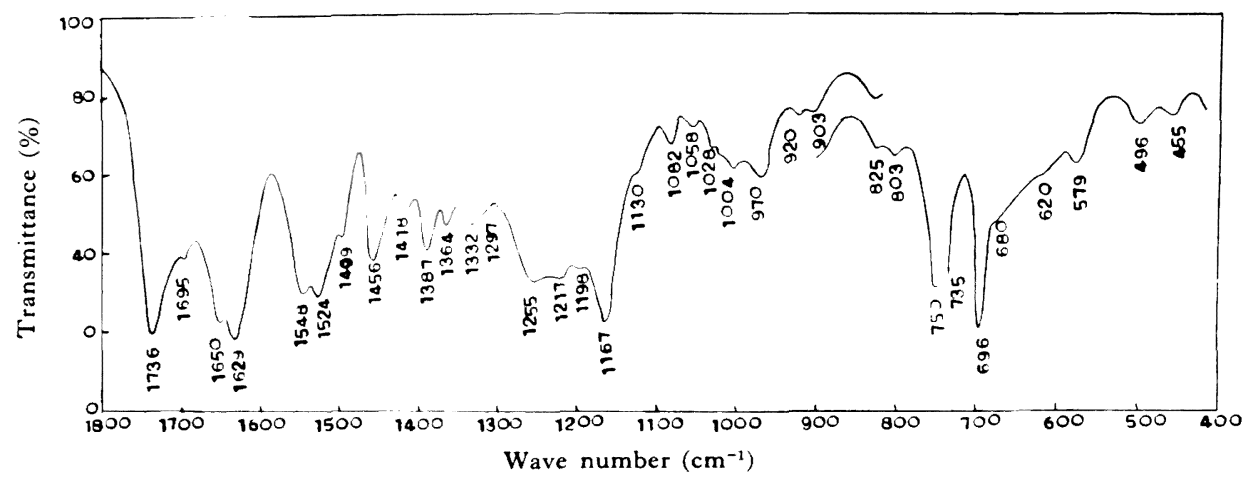

Fig. 7. Infrared spectra of poly benzyl L-glutamate $A / I=8$.

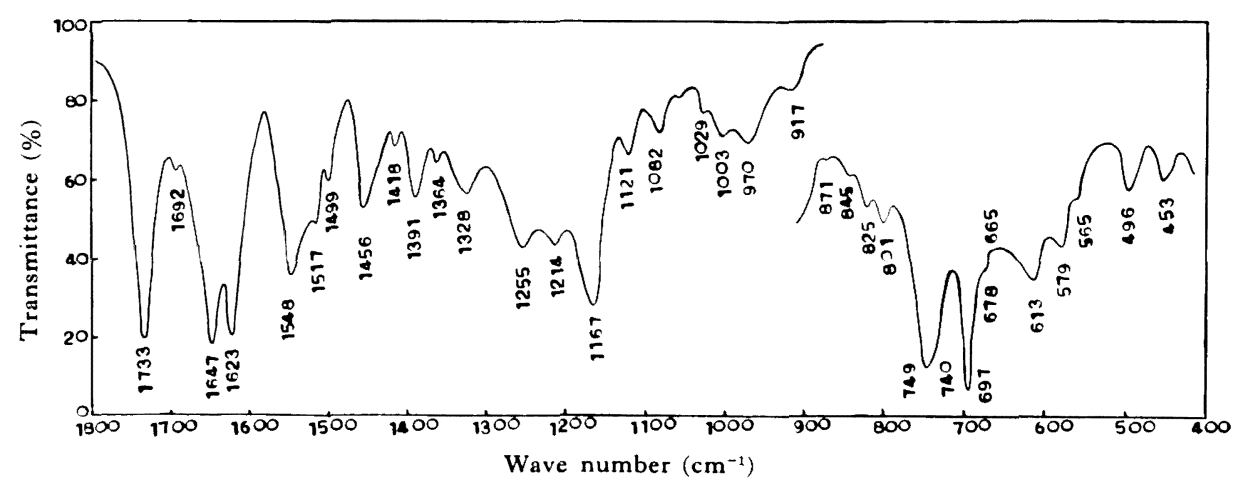

Fig. 8. Infrared spectra of poly benzyl L-glutamate $A / I=20$.

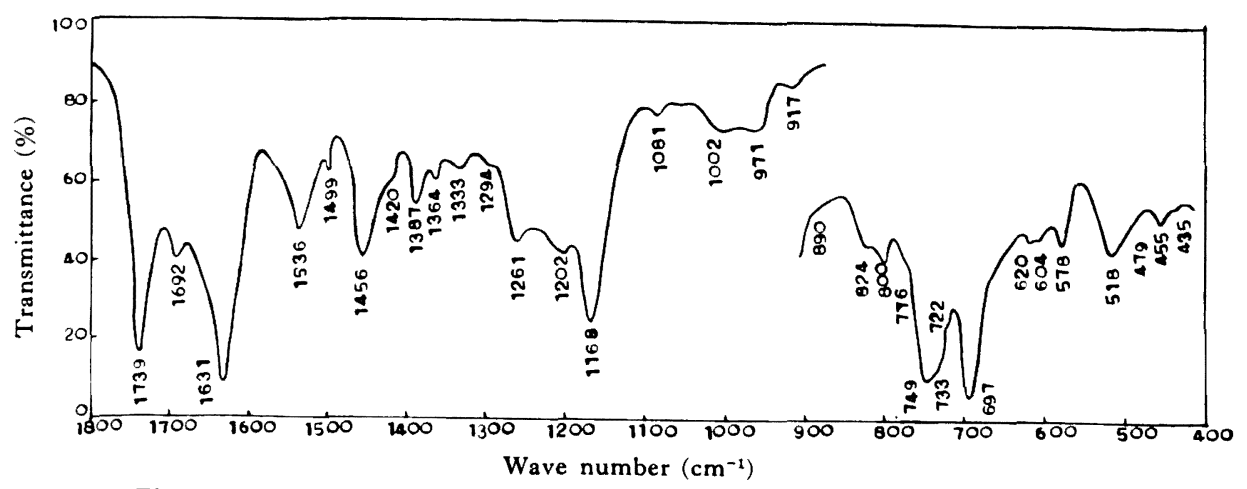

Fig. 9. Infrared spectra of $\mathrm{N}$-deuterated poly benzyl L-glutamate $A / I=4$. 
次に低重合度重合体の $\beta$ 型構造泉によるアミド V 吸 収帯を調べるのであるが, ポリグルタミン酸メチルでは $700 \mathrm{~cm}^{-1}$ に存在したのでベンジルェステルでも, 同じあ たりに見られると予想される。しかるにベンジルェステ ルでは 750 700 $\mathrm{cm}^{-1}$ にベンゼン核 $\mathrm{CH}$ 面外変角振動 による 2 本の強い吸收帯があるため，直接には見出しに くいことがわかった。Fig. 6 8 まで, $A / I=4,8,20$ の
PBLG の測定結果を示した。 $A / I=4,8$ ではアミド I, II より $\beta$ 型構造をとっていることが明らかである。 $615 \mathrm{~cm}^{-1}$ あたりは吸収帯はない。 $A / I=20$ では, アミド I, II より $\alpha, \beta$ 両型の混在が推定されるが, 低波数領域 では $613 \mathrm{~cm}^{-1}$ に吸収帯があり, $565 \mathrm{~cm}^{-1}$ のものも見ら れる。これは両者とも $\alpha$-Helix によるものである。 次に $\mathrm{N}$ 重水素化試料についての測定を Fig. 9 11 ま

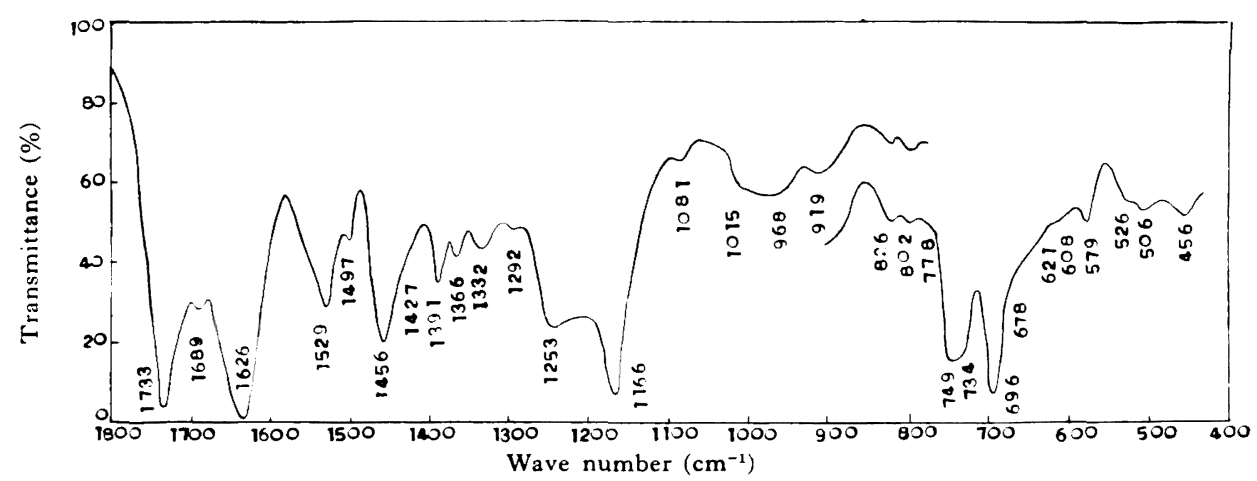

Fig. 10. Infrared spectra of $\mathrm{N}$-deuterated poly benzyl L-glutamate $A / I=8$

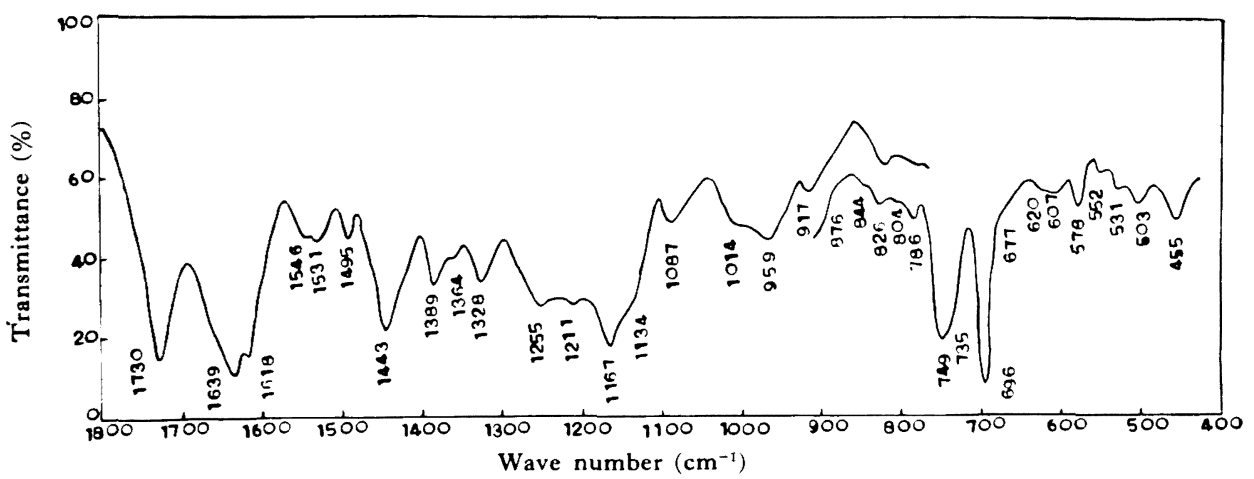

Fig. 11. Infrared spectra of $\mathrm{N}$-deuterated poly benzyl L-glutamate $A / I=20$.

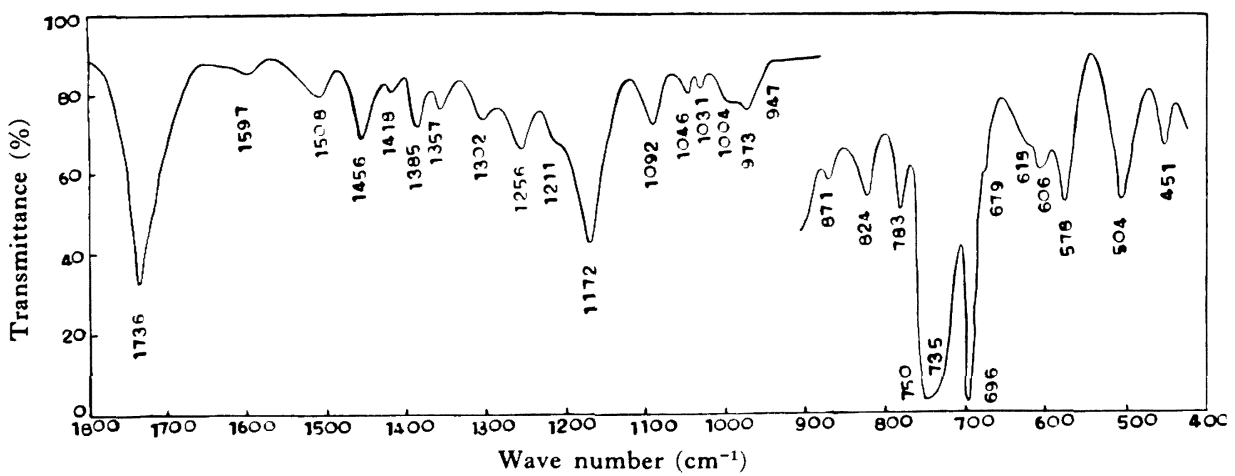

Fig. 12. Infrared spectra of benzyl $n$-butyrate. 
でに示す。 $A / I=4-\mathrm{d}$ で $518 \mathrm{~cm}^{-1}$ に新しい吸収帯がみ られる。これはアミド V と推定されるが, 理論波数比 1.34 を用いて計算すれば $693 \mathrm{~cm}^{-1}$ あたりにあったア ミド V が重水素によって移動したものとして理解され る。 $A / I=8-\mathrm{d}$ の試料では $526 \mathrm{~cm}^{-1}$ にわずかであるが 吸収帯が生じ，これも $700 \mathrm{~cm}^{-1}$ あたりより移動したも のであろう。 $A / I=20-\mathrm{d}$ では $613 \mathrm{~cm}^{-1}$ は $455 \mathrm{~cm}^{-1}$ 人 移り $(455 / 613=1 / 1.33)$, また $531 \mathrm{~cm}^{-1}$ にも新しい $\beta$ 型 のアミド V'が見られる。比較のため同じ側鎖をもつ $n$ 酪酸ベンジルの赤外線吸收を Fig. 12 に示した。注目 の $620 \sim 600 \mathrm{~cm}^{-1}$ には強い吸収帯はないので, アミド V が強く現われうるわけである。

以上をまとめると，ポリグルタミン酸ベンジルでもア ミド V 吸收帯は, $\alpha$-Helix 構造のとき $\sim 615 \mathrm{~cm}^{-1}$ に 見られ、 3 型構造のときおそらくは 700 690 $\mathrm{cm}^{-1}$ あ たりに存在していることが明らかになった。このことは メチルェステルの結果とほとんど同じで，分子構造の解 明に有用な吸収帯として、ここに確定したわけである。

付 記: 本研究は日本化学会第 14 年会 (昭和 36 年)で報告 した。本研究は昭和 35 年大阪大学蛋白質研究所共同研究員制
度によって行なわれた。ご指䆃いただいた同研究所宮沢辰雄目 教授、およびご援助いただいた物理棈造部、溶液学部の方々に 感謝する。また合成に際して、ご助力いただいた北海道大学里 口順藏教授にお礼を申上げる。

\section{文献}

1）增田幸夫：高化, 20, 161(1963)

2) 宮沢辰雄：日化, 77, 526(1956)

3）増田幸夫：高化， 20，166(1963)

4) T. Miyazawa, E. R. Blout : J. Am. Chem. Soc., 83, 712(1961)

5) E. R. Blout, R. H. Karlson: J. Am. Chem. Soc., 78, 941(1956)

6) E. R. Blout, A. Asadourian: J. Am. Chem. Soc., 78, 955(1956)

7) P. Doty, J. H. Bradbury, A. M. Holzer: J. Am. Chem. Soc., 78, 947(1956)

8) E. Elliott, B. R. Malcolm: Proc. Roy. Soc. Lon. don, A 249, 30(1959)

9) 3 構造の PBLG の研究は, 最近ではたとえば A. Wada et al: J. Phys. Chem., 65, 1119(1961)

\section{Molecular Structures of Polyglutamate}

\section{Infrared Absorption Spectra of Poly $\gamma$-Benzyl Glutamate}

By Yukio Masuda*

Solid films of poly $\gamma$-benzyl glutamate were prepared, and their infrared absorption spectra were measured. It was observed that in the low frequency region the amide $\mathrm{V}$ band due to $\mathrm{N}-\mathrm{H}$ out-of-plane deformation mode varies sensitively with the change of molecular conformation. The $\alpha$-Helix amide $\mathrm{V}$ band appears at $615 \mathrm{~cm}^{-1}$, while the $\beta$-structure amide $\mathrm{V}$ band appears at about $700 \mathrm{~cm}^{-1}$. This is a significant difference similarly to that for poly methyl glutamate.

* Department of Physics and Chemistry, Gakushuin University (1-Chome, Mejiro, Toshima, Tokyo) 